\title{
THE RATIONALE OF HIGH VASCULAR LIGATION IN SURGERY FOR LEFT SIDED COLON CANCER
}

\author{
Narimantas Evaldas Samalavičius ${ }^{1}$, Audrius Dulskas ${ }^{2}$, Simonas Ūselis ${ }^{2}$, Edgaras Smolskas ${ }^{2}$ \\ ${ }^{1}$ Chief of Department of Surgery, Klaipeda University Hospital, Lithuania, \\ ${ }^{2}$ Department of General and Abdominal Surgery and Oncology, \\ National Cancer Institute, Lithuania
}

Key words: laparoscopic surgery, left sided colon cancer, high ligation, lymphnode harvest.

\begin{abstract}
Summary
Background. The aim of the study was to evaluate the safety and adequacy of high vascular ligation while performing surgery for left-sided colon cancer. We performed a retrospective analysis of prospectively collected data of patients operated laparoscopically for sigmoid or descending colon cancer in a single tertiary care institution over a period of 10 years. Patients and methods. Between January 2007 and December 2016 hand-assisted laparoscopic surgery (HALS) was performed on 228 patients due to invasive and histologically verified descending or sigmoid colon cancer with high ligation of inferior mesenteric artery and vein. Patients who had carcinoma in situ were excluded. The following variables were collected and prospectively studied: age, sex, cancer localization, cancer stage, type of surgery, operative time, lymph node harvest, intraoperative complications, conversions, duration of hospital and postoperative stay, postoperative complications occurring within 30 days. Complications were assessed by ClavienDindo classification.
\end{abstract}

Results. Patient mean age was $64 \pm 10$ years (range, 40 - 86). There were 112 females (49.1\%) and 116 males $(50.9 \%)$. A total of $149(65.5 \%)$ sigmoid colectomies and 79 (34.5\%) left hemicolectomies have been performed. There were total of $71(31 \%)$ patients with stage I disease, 67 (29.7\%) - stage II, 65 $(28.4 \%)$ stage III and 25 (10.9\%) stage IV. Aerage operative time was $105 \pm 39$ minutes (range, 45-270). Average harvested lymph node count was $16.5 \pm 10$ (range, 10 - 90). Length of postoperative stay was $6.3 \pm 3.2$ days (range, 1-30). Eleven (4.82\%) patients had complications, three of them $(1,3 \%)$ were reoperated. There was no anastomotic leakage detected in this group of patients.

Conclusions. Our data support the opinion, that high vascular ligation while performing surgery for left sided colon cancer is safe. Recorded lymphnode harvest confirms oncological adequacy of such an approach.

\section{Introduction}

Despite a large number of articles in the literature up to date on high versus low (more correctly intermediate - below left colic artery (LCA)) ligation of inferior mesenteric artery (IMA) while performing surgery for left sided colon or rectal cancer, there is still controversy which kind of ligation should be routinely performed. More than a hundred years ago, regardless that understanding of many mechanisms of cancer was still lacking, British surgeon Moynihan (1) noted that "for cancer of the sigmoid flexure and rectum, it requires removal of the growth and healthy intestine on each side of it, and the excision of all glands which lie along the arteries as far as the mesenteric inferior artery at its origin from the aorta". The concept of high ligation to achieve adequate lymphatic clearance was very straightforward and was practiced by many surgeons for years. Alternative approach has been also used - preservation of LCA and ligation of IMA just below the orifice of LCA. Two important studies came out of St. Marks hospital comparing high versus low ligation for rectal and rectosigmoid cancer -though both retrospective in nature - demonstrating no survival benefit in either group $(2,3)$. High ligation of IMA in a way lost its sacramental significance. In addition, possible adverse effect of high IMA ligation related to poorer blood supply in proximal colon compared to preserved LCA in surgery for rectal cancer was reported (4), and doing less safe rather than more with no clear advantage sounded reasonable. 
Table 1. Hand-assisted laparoscopic surgical (HALS) procedures performed in 228 patients due to descending or sigmoid colon cancer.

\begin{tabular}{|l|l|l|}
\hline HALS procedure & Number & Percent (\%) \\
\hline Left hemicolectomy & 79 & 34.5 \\
\hline Sigmoid colectomy & 149 & 65.5 \\
\hline Total & 228 & 100 \\
\hline
\end{tabular}

Our study aimed to evaluate the safety and adequacy of high vascular ligation while performing surgery for left sided colon cancer. We performed a retrospective analysis of prospectively collected data of patients operated laparoscopically for sigmoid or descending colon cancer in a single tertiary care institution over a period of 10 years.

\section{Patients and methods}

Between 2007 and 2016 all patients undergoing handassisted laparoscopic surgery (HALS) for left sided colon and rectal cancer in a single tertiary care institution (National Cancer Institute) were included in a prospective database a total of 473 patients were identified. We made a detailed analysis of 228 patients from above mentioned group who underwent HALS due to invasive and histologically verified descending or sigmoid colon cancer. All of them underwent either laparoscopic hand assisted left hemicolectomy or laparoscopic hand assisted sigmoid colectomy depending on the localization of the tumour. Patients who had carcinoma in situ were excluded from the study. The following variables were collected and prospectively studied: age, sex, cancer localization, cancer stage, type of surgery, operative time, lymph node harvest, intraoperative complications, conversions, duration of overall and postoperative stay, postoperative complications occurring within 30 days. Complications were assessed by Clavien-Dindo classification.

Surgical technique.

Through $6-6.5 \mathrm{~cm}$ transumbilical incision a hand port (Dextrus, Ethicon Johnson and Johnson, USA) was introduced into the abdomen. Additional two ports on the right side -10 and 12 (camera and operative ports respectively) - were introduced using hand control. For mobilization of splenic flexure, additional $5 \mathrm{~mm}$ port in the left iliac region

Table 3. Intraoperative and postoperative outcomes of surgical procedures.

\begin{tabular}{|l|c|c|c|c|c|}
\hline \multirow{2}{*}{} & \multicolumn{4}{|c|}{ Cancer stage } & \multirow{2}{*}{ Total } \\
\cline { 2 - 5 } & I & II & III & IV & \\
\hline Left hemicolectomy & $26(32.9 \%)$ & $26(32.9 \%)$ & $24(30.4 \%)$ & $3(3.8 \%)$ & $79(34.5 \%)$ \\
\hline Total & $45(30.2 \%)$ & $41(27.5 \%)$ & $41(27.5 \%)$ & $22(14.8 \%)$ & $149(65.5 \%)$ \\
\hline
\end{tabular}

Table 2. Stages of descending or sigmoid colon cancer.

\begin{tabular}{|l|c|c|}
\hline Variables & Value & Range \\
\hline Operative time (minutes) & $104( \pm 38)$ & $45-270$ \\
\hline The average lymph node harvest & $16,5( \pm 10)$ & $10-90$ \\
\hline Postoperative stay (days) & $6,3( \pm 3,2)$ & $1-30$ \\
\hline Inn-hospital stay (days) & $8,5( \pm 3,9)$ & $2-34$ \\
\hline
\end{tabular}

was used. With surgeon on the right side and the patient in a head down position, lateral to medial mobilization of the left colon was performed. After doing so, incision in the peritoneum was made on the right side of the mesentery at the level of promontorium, and IMA was mobilized all the way up to1-2 $\mathrm{cm}$ from the aorta and ligated after identifying the left ureter, and taking care and preserving autonomic nerves. Further on, a mobilization and high ligation of inferior mesenteric vein was done.

Descriptive statistics for qualitative data are presented in frequency tables, for quantitative data mean values with standard deviations are presented. Data were analysed using IBM SPSS Statistics 21 statistical analysis software.

\section{Results}

Mean patients age was $64 \pm 10$ years (range, 40 - 86). There were 112 females (49.1\%) and 116 males (50.9\%). A total of $149(65.5 \%)$ sigmoid colectomies and $79(34.5$ $\%)$ left hemicolectomies have been performed (Table 1). There were total of 71 (31\%) patients with stage I disease, $67(29.7 \%)$ - stage II, 65 (28.4\%) stage III and 25 (10.9 \%) stage IV (Table 2). Average operative time was $105 \pm 39$ minutes (range, 45-270). Average harvested lymph node count was $16.5 \pm 10$ (range, 10 - 90). Length of postoperative stay was 6.3 \pm 3.2 days (range, 1-30) (Table 3). Eleven (4.82\%) patients had complications (Table 4). One occurred during operation due to a bleeding from mesenteric vessels caused by malfunction of suturing device, a conversion to laparotomy has been performed in order to ligate mesenteric artery and vein. One patient after operation was diagnosed with bowel obstruction due to intraabdominal infiltration of anastomotic site, no intervention has been performed. After administration of antibiotics, clinical symptoms of intestinal obstruction diminished and patient recovered. Most of postoperative complications were grade II by Clavien-Dindo classification - six $(2.63 \%)$, one $(0.4 \%)$ - IIIa and three $(1.32 \%)$ were IIIb. Briefly, a patient clinically diagnosed with peritonitis, underwent laparotomy 
- perforation of small intestine was found. Perforation was sutured and cavity of abdomen washed out and drained. One case of postoperative intraabdominal bleeding was managed by laparotomy. One patient with intraabdominal abscess underwent laparotomy with washing and a loop ileostomy. Subsequently all patients successfully recovered and were discharged from hospital.

\section{Discussion}

In this study with 228 unselected patients (among them approximately $50 \%$ having one or more comorbidities) who underwent laparoscopic hand assisted left hemicolectomy or sigmoidectomy for sigmoid or descending colon cancer with high ligation of IMA we did not have a single anastomotic leakage over the period of 10 years. Thus we reviewed all the objective data in the literature on reduction of blood flow in the colon proximal to anastomosis after ligation of IMA at the level of aorta, not preserving LC artery. Dworkin et $a l$ while investigating influence of clamping of IMA and its influence on the blood flow of sigmoid colon used Doppler flowmetry (4). They measured blood flow change during mobilization of the sigmoid colon before excision of sigmoid colon or rectum in 26 patients and monitored blood flow proximal to colorectal anastomosis during five postoperative days in five patients. The significant fall of sigmoid colon serosal flow after ligation was recorded and no increase of perianastomotic colonic perfusion was noted during first five postoperative days. No correlation with surgical results was determined. Seike et al measured colonic blood flow proximal to anastomosis in 96 patients using Doppler flowmetry while clamping IMA or LCA (5). Only ten of those patients were operated for sigmoid, and all the rest - for rectal cancer. They concluded that colonic blood flow at the proximal site of the anastomosis was significantly decreased by either IMA or LCA clamping, and that IMA clamping was related with marked reduction of blood flow especially in elderly and male patients. As an example, three elderly patients received IMA clamping were among the 19 who demonstrated more that 50 percent of reduction of blood flow - and two of them suffered from severe anastomotic ischaemia. Both

Table 4. Intraoperative and postoperative complications of 228 hand-assisted laparoscopic procedures.

*Due to intrabdominal infiltration of anastomotic site, no intervention had been performed.

** Caused by perforation of small intestine.

*** Due to a bleeding from mesenteric vessels caused by non-functioning suturing device.

\begin{tabular}{|c|c|c|c|c|c|c|}
\hline Operation & Complication & Patients & Rate & Management & Outcome & $\begin{array}{c}\text { Clavien - } \\
\text { Dindo }\end{array}$ \\
\hline Sigmoid colectomy & Cardiac anrythmia & 1 & 0,4 & Conservative & Reoceverd & II \\
\hline Sigmoid colectomy & Wound infection & 1 & 0,4 & Conservative & Recovered & II \\
\hline Left hemicolectomy & $\begin{array}{l}\text { Subacute intestinal } \\
\text { obstruction* }\end{array}$ & 1 & 0,4 & Conservative & Recovered & II \\
\hline Left hemicolectomy & Sepsis & 1 & 0,4 & Conservative & Recovered & II \\
\hline Sigmoid colectomy & Wound infection & 1 & 0,4 & Drainage & Recovered & II \\
\hline Left hemicolectomy & Uninary retention & 1 & 0,4 & Epicystostomy & Recovered & IIIa \\
\hline Left hemicolectomy & $\begin{array}{l}\text { Intraabdominal } \\
\text { bleeding }\end{array}$ & 1 & 0,4 & Laparotomy, hemostasis & Recovered & IIIb \\
\hline Sigmoid colectomy & Peritonitis** & 1 & 0,4 & Laparotomy & Recovered & IIIb \\
\hline Left hemicolectomy & $\begin{array}{c}\text { Intraabdominal } \\
\text { abscess }\end{array}$ & 2 & 0,88 & $\begin{array}{c}\text { Conservative/Laparoto } \\
\text { my, washout, loop } \\
\text { ileostomy }\end{array}$ & Recovered & II/IIIb \\
\hline Left hemicolectomy & Conversion ${ }^{* * *}$ & 1 & - & - & Recovered & - \\
\hline Total & - & 11 & 4,82 & - & - & - \\
\hline
\end{tabular}


of them underwent ultralow anterior resection, and no such evidence was demonstrated in sigmoid cancer patient group. Komen et al used Doppler flowmetry in 33 patients -16 underwent high tie with ligation of IMA and 17 low tie with preservation of LCA (6). All patients were operated for rectal cancer. Blood flow was higher in low ligation group, but it did not have a reflexion on surgical results - there was one anastomotic leakage in each group. Guo et al used marginal artery stump pressure measurements in 57 Chinese patients undergoing rectal cancer surgery, randomly distributed in two groups: high IMA ligation and low ligation with preservation of LCA and removal of lymph nodes around the IMA root (7). Patients with preserved LCA had better blood supply, but very importantly they demonstrated that anastomotic blood supply negatively and linearly correlated with distal colon length. There was no difference in anastomotic leakage rate in both groups. Summarizing these four studies, it should be noted that most of them are conducted with rectal cancer patients, and this is not the same colon which we use for anastomosis as after left hemicolectomy or sigmoidectomy. One study clearly demonstrated that marginal artery stump pressure is related with distal colon length (7), thus effect of IMA high ligation has objectively more impact for the colon which is used for anastomosis after rectal resection than after surgery for left colon cancer. Besides, additional factors are related with anastomotic leakage in rectal cancer surgery compared to colon cancer surgery, and rates of leakage are much higher after surgery for rectal cancer. So we have no objective data in the published literature to prove that clinically significant reduction of blood flow after left hemicolectomy or sigmoidectomy while performing high IMA ligation exists, and there is no data to support the fact that reduction of blood flow is so severe that can be proved to be related with incidence of anastomotic leakage or safety of anastomotic integrity.

Tocchi et al in a study where resection of the left colon was performed for diverticular disease divided patients into two groups: in one group (77 patients) IMA of was ligated at its origin near aorta and in the other group (86 patients) preserved after skeletisation: they found statistically significant lower incidence of anastomotic leakage in a group with preserved IMA (8). However, the essence of this result is the fact that in a group with IMA preservation the blood supply to superior rectal artery was intact too, and likely the positive benefit of the low ligation was related not only with better blood supply to proximal colon, but more importantly with proper blood supply to the upper rectum.

In colon cancer surgery, the aim of the high ligation is to improve overall survival by removing all the possible deposits of lymphatic regional cancer spread. In recent de- cades, a concept of total mesocolic excision (CME) has been introduced by Hohenberger using similar philosophy as was used describing total mesorectal excision for rectal cancer. His improvement in reduction of local recurrence rates and 5 year survival are impressive, and the key points are high vascular ligation and completeness of regional excision of all possible cancer draining tissues while following embryonic mesocolic planes (9). In the latter study, from a total number of 1329 patients more than half $(58.5 \%)$ were treated for sigmoid or descending colon cancer. It is undeniable that his CME concept in right hemicolectomy is different, while his CME principles in left hemicolectomy or sigmoidectomy are very similar to generally accepted ones, core point being high vascular ligation. It justifies our strategy to perform high ligation of IMA aiming to best possible oncological results. Again, we did not have any adverse effect of high ligation in terms of safety of anastomosis in a large group of unselected 228 patients.

Slanetz CA and Grimson R evaluated data on 2409 consecutive patients operated on for colorectal cancer with curative intent in Columbia-Presbytarian Medical Center (10). Operative data (including level of vascular ligation) and pathology reports were well documented. They found statistically significant survival benefit in favour of high ligation: in stage II and in certain subgroups of patients having stage III colorectal cancer. There was lower incidence after high ligation of local recurrence and suture line recurrence in patients with stage II and III. Kanemitsu et al (11) looked at the incidence and distribution of metastatic lymph nodes in relation to survival benefit after high ligation of IMA in station 253 (proximal to origin of left colic artery) and station 252 (through the bifurcation of the superior rectal artery) according to Japanese criteria (12). They demonstrated incidence of metastatic lymph nodes in colorectal cancer to be $1.8 \%$ in station 253 and $8.3 \%$ in station 252 . In their hands, high ligation allowed curative resection and long-term survival in patients with nodal metastasis in these stations. Alici et al examined specimens of 103 patients who underwent high ligation for left sided colon and rectal cancer, paying special attention to apical node (13). They found tumour invasion in the apical nodes in $5.8 \%$ of patients (above left colic artery), and in $1.9 \%$ of these cases even skip metastasis were noted: no other lymph node metastasis were determined apart from the apical localization; on an average 4.4+-3.2 apical lymph nodes were harvested. An interesting observation was described in a study from Taiwan where all patients underwent high ligation (14). They found apical - IMA root - metastasis in 3.1\% of cases from 1389 colorectal cancer patients reviewed. Despite the fact that large number of those having IMA metastasis developed tumour recurrence or metastasis, 
a true survival benefit was observed in a subgroup of those patients who were operated for T4 sigmoid cancer. A systematic review on high versus low ligation of LCA in left colon and rectal cancer Titu et al reviewed one randomized trial, seven quasi-experimental and eight retrospective cohort studies (15). A total of 7649 patients were analysed, of them 4849 underwent high ligation. Although they could not find evidence of improved survival in high ligation group, latter technique contributed to improved lymph node retrieval and accuracy of tumour staging.

An alternative technique to high ligation of IMA was introduced - a low ligation with lymph node dissection (LND) around the origin of IMA. Yasuda et al compared 42 patients who underwent high ligation with 147 who underwent low ligation with LND (16). In all parameters both groups were equal: lymph node harvest, overall and relapse-free survival regardless of the presence or absence of metastatic nodes. Sakimoto et al showed that if low ligation with LND is performed laparoscopically, it gives equivalent clearance compared to high ligation as well, and is not related with excessive operative time or bleeding (17). Yet larger prospective studies are needed to confirm the role of low ligation and LND in left sided colon or rectal cancer surgery.

Our data support the opinion, that high vascular ligation while performing surgery for left sided colon cancer is safe. Recorded lymph node harvest after 228 left hemicolectomies or sigmoid resections in our study confirms oncological adequacy of such an approach.

Conflicts of interest: authors declare no conflicts of interest.

\section{References}

1. Moynihan BG. The surgical treatment of cancer of sigmoid flexure and rectum. Surg Gynecol Obstet 1908;6:463-466.

2. Pezim ME, Nicholls RJ. Survival after high or low ligation of the inferior mesenteric artery during curative surgery for rectal cancer. Ann Surg 1984;200:729-733.

https://doi.org/10.1097/00000658-198412000-00010

3. Surtees P, Ritchie JK, Phillips RK. High versus low ligation of the inferior mesenteric artery in rectal cancer. Br J Surg 1990;77:618-621.

https://doi.org/10.1002/bjs. 1800770607

4. Dworkin MJ, Allen-Mersh TG. Effect of inferior mesenteric artery ligation on blood flow in the marginal artery-dependant sigmoid colon. J Am Coll Surg 1996;183:337-360.

5. Seike K, Koda K, Saito N, Oda K, Kosugi S, Smimizu K, Miyazaki M. Laser Doppler assessment of the influence of division of the root of inferior mesenteric artery on anastomotic blood flow in rectosigmoid cancer surgery. In J Colorect Dis 2007;22:689-697. https://doi.org/10.1007/s00384-006-0221-7

6. Komen N, Slieker J, Kurt P, de Wilt LHW, Harts E, Cuene PP, Gosselink M, Tetteroo G, de Graaf E, van Beek T, van Toom R, van Boekel W, Verhoef C, Lange JF. High tie versus low tie in rectal surgery: comparison of anastomotic perfusion. In J Colorect Dis 2011;26:1075-1078.

https://doi.org/10.1007/s00384-011-1188-6

7. Guo Y, Wang D, Liang H, Zhang Y, Zhao S, Zhang L, Sun X, Suo J. Marginal artery stump pressure in the left colic arterypreserving rectal cancer surgery: a clinical trial. ANZ J Surg 2017;87(7-8):576-581.

https://doi.org/10.1111/ans.13032

8. Tocchi A, Mazzoni G, Fornasari V, Miccini M, Daddi G, Tagliacozzo S. Preservation of the inferior mesenteric artery in colorectal resection for complicated diverticular disease. Am J Surg 2001;182:162-167.

https://doi.org/10.1016/S0002-9610(01)00681-X

9. Hohenberger W, Weber K, Matzel K, Papadopoulos T, Merkel S. Standardized surgery for colonic cancer: complete mesocolic excision and central ligation - technical notes and outcome. Colorectal Disease 2009;11:354-365.

https://doi.org/10.1111/j.1463-1318.2008.01735.x

10. Slanetz CA, Crimson R. Effect of high and intermediate ligation on survival and recurrence rates following curative resection of colorectal cancer. Dis Colon Rectum 1997;40(10):1205-1219. https://doi.org/10.1007/BF02055167

11. Kanemitsu Y, Hirai T, Komori K, kato T. Survival benefit of high ligation of the inferior mesenteric artery in sigmoid colon and rectal cancer surgery. Br J Surg 2006;93:609-615.

https://doi.org/10.1002/bjs.5327

12. Japanese Society for cancer of the Colon and Rectum. General rules for clinical and pathological studies on cancer of the colon, rectum and anus (6th edn). Kanaharra Shupan:Tokyo, 1998.

13. Alici A, Kement M, Gezen C, Akm T, Vural S, Okkabaz N, Basturk E, Yegenoglu A, Oncel M. Apical lymph nodes at the root of the inferior mesenteric artery in distal colorectal cancer: an analysis of the risk of tumor involvement and the impact of high ligation on anastomotic integrity. Tech Coloproctol 2010;14:1-8.

https://doi.org/10.1007/s10151-009-0547-6

14. Chin C, Yeh C, Tang R, Changcien C, Huang W, Wang J. The oncological benefit of high ligation of the inferior mesenteric artery in the surgical treatment of rectal and sigmoid cancer. Int J Colorect Dis 2008;23:783-788.

https://doi.org/10.1007/s00384-008-0465-5

15. Titu LV, Tweedle E, Rooney PS. High tie of the inferior mesenteric artery in curative surgery for lefy -colonic and rectal cancers: a systematic review. Dig Surg 2008;25:148-157. https://doi.org/10.1159/000128172

16. Yasuda K, Kawai K, Ishihara S, Murono K, Otani K, Nishikawa T, Tanaka T, Kiyomatsu T, Hata K, Nozawa H, Yamaguchi H, Aoki S, Mishima H, Maruyama T, Sako A, Watanabe T. Level 
of arterial ligation in sigmoid colon and rectal cancer surgery. World Journal of Surgical Oncology 2016;14:99.

https://doi.org/10.1186/s12957-016-0819-3

17. Sekimoto M, Takemasa I, Mazushima T, Ikeda M, Yamamoto H, Doki Y, Mori M. Laparoscopic lymph node dissection around the inferior mesenteric artery with preservation of left colic artery. Surg Endosc 2011;25:861-866.

https://doi.org/10.1007/s00464-010-1284-7

\section{"AUKŠTO" KRAUJAGYSLIŲ PERRIŠIMO, ATLIEKANT OPERACIJAS DE்L KAIRÉS PUSĖS GAUBTINĖS STOROSIOS ŽARNOS VĖŽIO, PAGRINDIMAS}

N. E. Samalavičius, A. Dulskas, S. Ūselis, E. Smolskas

Raktažodžiai: laparoskopinė chirurgija, kairès pusės gaubtinės

žarnos vėžys, "aukštas" perrišimas, limfmazgių skaičius.

Santrauka

Tikslas. Šio darbo tikslas buvo įvertinti ,aukšto“ kraujagyslių perrišimo saugumą ir patikimumą atliekant laparoskopines operacijas dèl invazinio kairès pusès gaubtinès storosios žarnos vèžio tretinio lygio gydymo ịstaigoje. Retrospektyviai buvo analizuoti perspektyviai per pastaruosius 10 metų surinkti duomenys.

Pacientai ir metodai. 2007-2016 metų laikotarpiu vienoje tretinio lygio įstaigoje buvo atliktos 228 laparoskopinès ranka asistuojamos operacijos dèl histologiškai verifikuoto invazinio riestinès ar nusileidžiančiosios gaubtinès storosios žarnos vėžio, atliekant "aukštą" apatinès pasaito arterijos ir venos perrišimą. Pacientai su carcinoma in situ nebuvo įtraukti. Buvo analizuojami šie duome- nys: amžius, lytis, vėžio lokalizacija, vèžio stadija, operacijos tipas, operacijos laikas, pašalintų limfmazgių skaičius, intraoperacinès komplikacijos, konversijos, bendra ir pooperacinè gulëjimo ligoninèje trukmé, pooperacinès komplikacijos, pasireiškusios per 30 dienų po operacijos. Komplikacijoms vertinti pasirinkta Clavien-Dido klasifikacija.

Rezultatai. Pacientų amžius buvo $64 \pm 10$ metų (nuo 40 iki 86), $112(49,1 \%)$ moterys ir $116(50,9 \%)$ vyrai. Iš viso buvo atliktos laparoskopinès ranka asistuojamos 149 (65,5\%) riestinès žarnos rezekcijos ir 79 (34,5\%) kairès hemikolektomijos. Pagal vėžio stadijas pacientai pasiskirstė taip: 71 (31\%) sirgo I stadijos, 67 (29,7 \%) - II, 65 (28,4\%) - III ir 25 (10,9\%) - IV. Vidutinė operacijos trukmè buvo $105 \pm 39$ minutès (nuo 45 iki 270). Vidutinis pašalintų limfmazgių skaičius buvo $16,5 \pm 10$ (nuo 10 iki 90). Vidutinè pooperacinio gulejjimo trukmè - 6,3 $\pm 3,2$ dienos (nuo 1 iki 30). Vienuolikos $(4,82 \%)$ pacientų pooperacinė eiga komplikavosi, o trys $(1,3 \%)$ buvo operuoti pakartotinai. Nei vienam pacientui pooperacinè eiga nesikomplikavo anastomozès siūlès nesandarumu.

Išvados. Mūsų duomenys patvirtino, jog "aukštas" apatinès pasaito arterijos ir venos perrišimas atliekant operacijas dèl kairès pusès gaubtinès storosios žarnos vėžio yra saugus. Limfmazgių, pašalintų šių operacijų metu, skaičius patvirtina šio tipo operacijų onkologinị patikimumą.

Adresas susirašinèti: narimantas.samalavicius@gmail.com

Gauta 2017-11-06 